\title{
Career Support Events for Students in Latvian Schools
}

\begin{abstract}
Rita Burceva
Rezekne Academy of Technologies

Abstract

The aim of the article is to identify and systematize the various career support events for students in Latvian schools. The research method is the study and content analysis of unpublished statistical documents of the State Education Development Agency.

The Latvian education system has a tendency to create appropriate circumstances for students to grow up as creative, erudite, and competent individuals. To promote the understanding of children and youth about the job world, the main activities in schools used to be group sessions in the framework of education programmes, episodic meetings with alumni, and excursions to companies. Nowadays significant changes can be observed in this field. In the research it was found that the number of school career counsellors in general education schools and technical schools in Latvia has grown more than five times. Professional school career counsellors provide a variety of career support events for students, and these can be systematized according to planning topics: performing student self-assessment (finding out one's strengths and weaknesses, listening to inspirational stories, trying artisan skills, etc.), getting to know the job world (excursions to companies and factories, job interview simulations, exploring the entrepreneurship environment and professions, etc.), exploring education opportunities (vocational, higher, and interest-related education), and making career decisions (setting their career goals, making career plans).
\end{abstract}

Keywords: career counselling, school career counsellors, variety of career support events 